\title{
Flexural Strength and Toughness Behaviour of Polymer Concrete with Partial Replacement of Fine Aggregate by M-Sand
}

\author{
P. Mugilvani, Mariyasubashini . L, Thendral. S
}

\section{1}

Abstract: The development segment for a structure solid assumes a significant job everywhere throughout the world the solid ought to have high compressive and flexural quality. Presently a day accessibility of regular assets is diminished due to the ecological issues are government limited sand quarries are supremacist in shortage and expands cost. So we need to move for the fake fine total in this paper rather than stream sand to assembling sand in incomplete supplant with SBR (polymer) in high quality on concrete different cement blends were assessed for compressive quality and Flexural quality. The common stream sand was mostly supplanted with $m$-sand by $0 \%, 25 \%$, half and included the different rates of $S B R$ latex $(0,3,6,9,12)$ was likewise improving the usefulness concrete. The outcome shows that the there is a step by step expanded in the compressive quality and Flexural quality for this situation half substitution of $\boldsymbol{m}$-sand and furthermore included the level of SBR increment the functionality However, further increases of $m$-sand caused a decrease in the quality. The ideal rate substitution of normal sand of $m$-sand is half and upgraded substance of polymer $9 \%$ is gotten. Diagrams were drawn and results contrasted and controlled blend.

Keywords - Flexural strength, M Sand, SBR Latex.

\section{INTRODUCTION}

The worldwide utilization of normal sand in exceptionally high, because of the broad utilization of cement or screen[1]-[3]. When all is said in done, the interest of normal sand is very high is creating nations to sit the fast foundation development, in this circumstance creating nation like in India, common sand store is being exhausted and making genuine natural just as the general public. Regular sand is endured and destroyed particles of rocks and are of different evaluations or size depending in the as indicated by wearing. Presently a day's fine total the prerequisite for colossal on the grounds that expanding in development exercises all through the world. Stream sand was utilized as fine total in numerous pieces of the world and subsequently the necessity for it is more. To take care of the above issues an other to stream sand is especially required of the fabricated sand.

Revised Manuscript Received on October 22, 2019.

P. Mugilvani, Department of Civil Engineering, Bharath Institute of Higher Education and Research, Chennai , India. Email: mugilvanipalanivel@gmail.com

Mariyasubashini - L, Department of Civil Engineering, Bharath Institute of Higher Education and Research, Chennai , India. Email: mariasubashini80@gmail.com

Thendral. S, Department of Civil Engineering, Bharath Institute of Higher Education and Research, Chennai , India. Email: thendral.cs@gmail.com
Stream sand (fine total), which is one of the constituents utilized in the creation of cement, has gotten costly and rare. So there is an enormous interest for elective materials. Examples 3D squares and crystal were set up for $(0 \%, 25 \%$, half) supplanting with $\mathrm{M}$-sand. Expanding the different measurements of super plasticize $(0 \%, 3 \%, 6 \%, 9 \%, 12 \%)$ by weight of cover improvement of its functionality properties just as mechanical properties with decreased water proportion. In this expansion the extent of substitution of was kept consistent at $25 \%$ of the heaviness of Fine total considering as a low level of $\mathrm{M}$ sand substitution[8]-[15]. It is retained that expansion of $\mathrm{M}$ sand diminishes the functionality of cement and it is repaid by the expansion of high range super plasticizer in concrete. Tests were led on a pressure testing machine and UTM. The outcomes are contrasted and the ordinary customary cement. M-s and characteristics itself as appropriate substitute for stream sand sensible cost, great degree and decent finish. Assembling sand has been utilized for the various exercises in the development business, for example, street development and production of building. Our undertaking presents the aftereffects of exploratory examinations did by $\mathrm{M}$-sand and subtleties of cement structured utilizing fabricating sand. The present investigation centers the use of mineral admixtures m-sand with polymer in concrete, profoundly non penetrable and to expand the general quality and utilize the materials for exceptional development applications[4]-[6].

\section{MATERIALS AND METHODS}

\section{A.Compressive Strength}

The compressive quality on 3D squares of size $150 \mathrm{~mm} \times 150 \mathrm{~mm} \times 150 \mathrm{~mm}$ were tried on a pressure testing machine. The solid with fractional substitution of regular sand by $\mathrm{M}$-sand with $0 \%, 25 \%$, half and there is a huge distinction in the quality with variety in measurement of SBR. In this way, halfway substitution of waterways and sand by M-s and expanding the compressive quality up to half. The test was led in 28 days and the test outcomes are arranged in the table. The compressive quality increment step by step because of increments in M-sand. 


\section{RESULTS AND DISCUSSION}

\section{A. Experimental Setup}

Pressure testing machine with a limit of 200 tones utilized with a stacking stage pace of $2 \mathrm{kN} / \mathrm{Sec}$. The subtleties of the test arrangement are appeared in figure: 1

After the underlying changes are applied over the heap step by step over the solid shapes. The test is completed by setting 3D shapes an example on a level plane between the stacking surfaces of a pressure test machine and the heap is applied to disappointment of the Cubes.

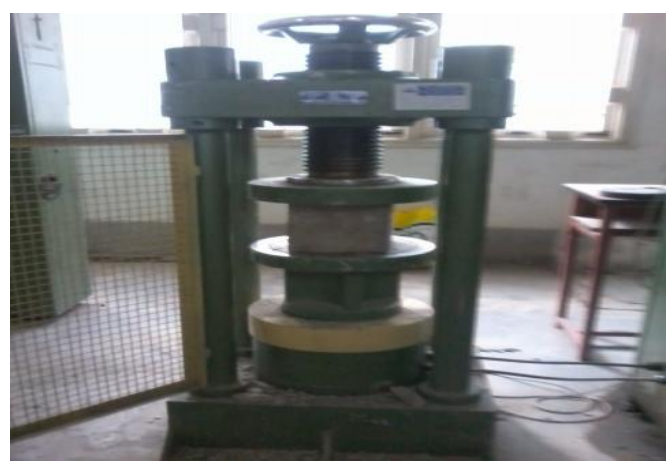

Figure:1 Compression Testing Machine with Specimen

\begin{tabular}{|c|c|c|c|c|c|}
\hline $\begin{array}{c}\text { S.N } \\
\mathbf{0}\end{array}$ & $\begin{array}{c}\text { Mix } \\
\text { id }\end{array}$ & $\begin{array}{c}\text { Cemen } \\
\mathbf{t} \\
\mathbf{k g} / \mathbf{m}^{\wedge} \mathbf{3}\end{array}$ & $\begin{array}{c}\text { M- } \\
\text { san } \\
\mathbf{d}\end{array}$ & $\begin{array}{c}\text { SBR } \\
\text { Late } \\
\mathbf{x} \\
\%\end{array}$ & $\begin{array}{c}\text { Compressiv } \\
\text { e strength } \\
\mathbf{2 8} \text { days }\end{array}$ \\
\hline 1 & $\begin{array}{c}\mathrm{M} \\
0\end{array}$ & 350 & 0 & 0 & 40.21 \\
\hline 2 & $\begin{array}{c}\mathrm{M} \\
1\end{array}$ & 350 & 177 & 3 & 41.24 \\
\hline 3 & $\begin{array}{c}\mathrm{M} \\
2\end{array}$ & 350 & 177 & 6 & 43.2 \\
\hline 4 & $\begin{array}{c}\mathrm{M} \\
3\end{array}$ & 350 & 177 & 9 & 44.27 \\
\hline 5 & $\begin{array}{c}\mathrm{M} \\
4\end{array}$ & 350 & 177 & 12 & 43.67 \\
\hline 6 & $\begin{array}{c}\mathrm{M} \\
5\end{array}$ & 350 & 355 & 3 & 42.21 \\
\hline 7 & $\begin{array}{c}\mathrm{M} \\
6\end{array}$ & 350 & 355 & 6 & 44.6 \\
\hline 8 & $\begin{array}{c}\mathrm{M} \\
7\end{array}$ & 350 & 355 & 9 & 45.68 \\
\hline 9 & $\begin{array}{c}\mathrm{M} \\
8\end{array}$ & 350 & 355 & 12 & 44.31 \\
\hline
\end{tabular}

Table 1:Test results of compressive strength

\section{B. Flexural Strength}

Crystal examples of size $500 \mathrm{mmx} 100 \mathrm{mmx} 100 \mathrm{~mm}$ were utilized cast and tried decide the flexural quality at 28 years old days. Crystal test every one of the blend in with different rates of M-Sand on $0 \%, 25 \%$, half with various dose of SBR $0 \%, 3 \%, 6 \%, 9 \%$ and $12 \%$ added to the quality thought. The example is then set in the UTM Machine in such a way, that nearby is applied to the highest surface as cast in the form, along two lines divided $13.3 \mathrm{~cm}$ separated[7]-[9]. The heap is improved until the example falls flat and the most extreme burden applied to the example during the test is recorded.

\section{FLEXURAL STRENGTH RESULTS}

The crystal tests every one of the blend in with different rates of M-Sand and different rates of SBR was tried to decide the flexural quality following 28 days utilizing a Universal Testing Machine. The tests were directed according to standard determinations it is appeared in table 2

\begin{tabular}{|l|l|l|c|c|c|}
\hline $\begin{array}{l}\text { S.N } \\
\mathbf{o}\end{array}$ & $\begin{array}{l}\text { Mi } \\
\mathbf{x} \\
\text { id }\end{array}$ & $\begin{array}{l}\text { Ceme } \\
\mathbf{n t} \\
\mathbf{k g} / \mathbf{m}^{\wedge} \\
\mathbf{3}\end{array}$ & $\begin{array}{l}\text { M- } \\
\text { san } \\
\mathbf{d}\end{array}$ & $\begin{array}{l}\text { SBR } \\
\text { Late } \\
\mathbf{x} \\
\mathbf{\%}\end{array}$ & $\begin{array}{l}\text { Flexur } \\
\text { al } \\
\text { strengt } \\
\mathbf{h} \\
\mathbf{2 8} \\
\text { days }\end{array}$ \\
\hline 1 & M0 & 350 & 0 & 0 & 4.44 \\
\hline 2 & M1 & 350 & 177 & 3 & 4.50 \\
\hline 3 & M2 & 350 & 177 & 6 & 4.60 \\
\hline 4 & M3 & 350 & 177 & 9 & 4.66 \\
\hline 5 & M4 & 350 & 177 & 12 & 4.63 \\
\hline 6 & M5 & 350 & 355 & 3 & 4.55 \\
\hline 7 & M6 & 350 & 355 & 6 & 4.67 \\
\hline 8 & M7 & 350 & 355 & 9 & 4.73 \\
\hline 9 & M8 & 350 & 355 & 12 & 4.66 \\
\hline
\end{tabular}

Table2: Test results of Flexural strength

\section{CONCLUSION}

-The river sand by a replacement of $\mathrm{m}$ - sand shows an improved in the compressive strength of the concrete.

- $\quad$ The river sand by a replacement of $\mathrm{m}$ - sand shows an improved in the Flexural strength of the concrete[10]-[13]. - Optimized content of $\mathrm{m}$-sand is $50 \%$ is obtained.

- The workability of the concrete gets reduced for $\mathrm{m}$-sand as compared to the river sand.

- A river sand by a replacement of m-sand with various percentages of polymer added increases the workability of the concrete.

- $\quad$ The results from the table show the decrease in the workability of concrete when the 12 percentages added in polymer.

- The optimum content of the polymer is $9 \%$ is obtained.

- The overall performance of polymer modified concrete increase compared to plain concrete.

\section{REFERENCES}

1. Sathish Kumar, K., Vinothkumar, S., Venkatakrishnaiah, R. \& Mohan, S.J. 2019, "Experimental investigation on rehabilitation of corroded concrete beam specimens", International Journal of Civil Engineering and Technology, vol. 10, no. 1, pp. 2949-2955.

2. Kanchanabhan, T.E., Krishnaiah R.V., Dayakar, P. and Mani, A., 
2019. A detailed study on green building concept in construction industry. International Journal of Civil Engineering and Technology, 10(1), pp. 2944-2948.

3. Mugilvani, P., Murugan, S.T., Kaviya, B. and Sathishkumar, K., 2019. Experimental investigation on nano concrete. International Journal of Civil Engineering and Technology, 10(1), pp. 907-912.

4. Vinothkumar, S., Sathishkumar, K., Anish, C. and Rajesh, S., 2019. Characteristic strength of concrete by partial replacement with sawdust and waste ceramic tiles. International Journal of Civil Engineering and Technology, 10(1), pp. 2821-2829.

5. Chitra, R., Thendral, S., Arunya, A. and Mohan, S.J., 2019. Experimental study on strength of concrete by partial replacement of fine aggregate with saw dust. International Journal of Civil Engineering and Technology, 10(1), pp. 2766-2769.

6. Mani, A., Meikandaan, T.P., Gowrishankar, P.G. and Kanchanabhan, T.E., 2019. A study on treatment of industrial effluent (dyeing) using moringa oleifera, tamarina indica as coagulants. International Journal of Civil Engineering and Technology, 10(1), pp. 2796-2811.

7. Frank Stephen, S., Chockalingam, M.P., Nalanth, N. and Lekshmy Raghavan, P., 2019. Study on the fresh state properties of self compacting concrete modified with recycled concrete aggregate. International Journal of Civil Engineering and Technology, 10(1), pp. 1205-1212.

8. Dayakar, P., Raman, K.V., Arunya, A. and Venkatakrishnaiah, R., 2019. Study on strength properties of sand by biocementation with eggshell. International Journal of Civil Engineering and Technology, 10(1), pp. 2770-2785.

9. Shendge, R.B., Chockalingam, M.P., Saritha, B. and Ambica, A., 2018. Swat modelling for sediment yield: A case study of Ujjani reservoir in Maharashtra, India. International Journal of Civil Engineering and Technology, 9(1), pp. 245-252.

10. Meikandaan, T.P. and Hemapriya, M., 2017. Use of glass FRP sheets as external flexural reinforcement in RCC Beam. International Journal of Civil Engineering and Technology, 8(8), pp. 1485-1501.

11. Harini, A.T., 2017. Experimental study on utilisation of ceramic wastes in concrete. International Journal of Civil Engineering and Technology, 8(8), pp. 1346-1352.

12. Ambica, A., Sartiha, B. and Anbarasan, R., 2017. Groundwater quality assessment using water quality index and GIS, Maduravoyal, Chennai, India. International Journal of Civil Engineering and Technology, 8(8), pp. 1375-1381.

13. Aswathy, M., Saritha, B. and Chockalingam, M.P., 2019. Degradation of anionic dye using Fe/Tio2 composite by photocatalysis. International Journal of Innovative Technology and Exploring Engineering, 8(9 Special Issue 3), pp. 788-

\section{AUTHORS PROFILE}

P. Mugilvani, Assistant Professor, Department of Civil Engineering, Bharath Institute of Higher Education and Research, Chennai , India.

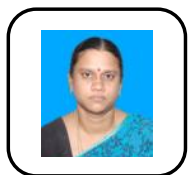

Mariyasubashini - L, Assistant Professor, Department of Civil Engineering, Bharath Institute of Higher Education and Research, Chennai , India

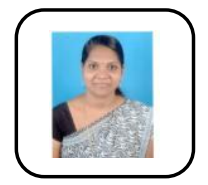

Thendral. S, Assistant Professor, Department of Civil Engineering, Bharath Institute of Higher Education and Research, Chennai, India. 